\title{
Release of Formaldehyde from Dimethylol Dimethylhydantoin, a Possible Antiseptic Agent ${ }^{\dagger}$
}

\author{
Hiroshi Maeda, Naoki Yamamoto, Takao Nagoya, \\ Kazu Kurosawa* and Fujio Kobayashi** \\ Department of Microbiology, Medical School, and Department of Chemistry,* \\ Faculty of Science, Kumamoto University, Kumamoto, Japan 860 \\ ** Tokyo Research Laboratory, Kowa Co., Ltd., \\ Higashi-Murayama, Tokyo, Japan 189 \\ Received February 17, 1976
}

\begin{abstract}
Dimethylol dimethylhydantoin (abbreviated as DMDMH), a water-soluble, stable, colorless and odorless hydantoin derivative, was investigated with various microorganisms for its potential applicability as an antiseptic agent. The possible mechanism of its action was elucidated. DMDMH inhibits bacterial and fungal growth at 15.6 to $250 \mu \mathrm{g} / \mathrm{ml}$, and HeLa S3 cells at $13.7 \mu \mathrm{g} / \mathrm{ml}$ by its continuous presence. Its removal after 1-hr incubation at 5,000 $\mu \mathrm{g} / \mathrm{ml}$ reversed the bacterial growth, thus indicating bacteriostatic action. The mechanism of action, in a study using a proton nuclear magnetic resonance, revealed a release of formaldehyde from DMDMH when $\mathrm{pH}$ was increased. Effect of DMDMH on antigenantibody reaction in agar gel showed no adverse effect at moderate concentration. Since its toxicity to animal was much less than that of mercurials or phenol, it can be useful as an antiseptic agent.
\end{abstract}

Mercurials, such as thimerosal or merthiolate have been widely used for antiseptic or preservative purposes in biological samples, particularly in preservation of antisera and other biological solutions. But recently environmental pollution by disposed matters posed a serious problem and led to termination of the practical use and production of the mercurials in Japan. Other antiseptic chemicals such as sodium azide and antibiotics are limited in applications, or they must be used either at relatively high concentration or at a possible risk of microbial contamination.

A hydantoin derivative, $\mathrm{N}, \mathrm{N}^{\prime}$ dimethylol dimethylhydantoin (DMDMH) ${ }^{23}$ is a highly water-soluble, colorless, stable and scentless chemical with very effective bacteriostatic effects. It is assumed to be biodegradable since the chemical contains no heavy metal per se but has a hydantoin structure. We would like to report here the chemical and biological characteristics of this compound as a possible antiseptic agent as well as the main

$\dagger$ Reprint requests should be addressed to H.M. mechanism of its action against microorganisms.

\section{MATERIALS AND METHODS}

Chemicals. DMDMH, DANTOIN ${ }^{\mathrm{R}}$, 1,3-bis(hydroxymethyl)-5,5-dimethyl-2,4-imidazolinedione was supplied as $55 \%$ aqueous solution from Glyco Chemicals Inc., Greenwich, Conn. The chemical structure is shown in Fig. 1. Formaldehyde was used after diluting formalin for biological assays or after distillation under reduced pressure for nuclear magnetic resonance (NMR) study. Formalin was obtained from Wako Pure Chemical Co., Osaka. Agar and media were obtained from Difco, Detroit, Mich. $\mathrm{D}_{2} \mathrm{O}$ and $40 \% \mathrm{NaOD}$ in $\mathrm{D}_{2} \mathrm{O}$ were from $\mathrm{E}$. Merck $\mathrm{AG}$., Darmstadt, Germany.

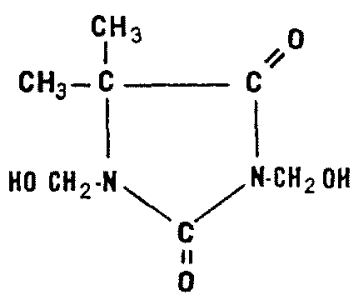

FIG. 1. Structure of Dimethylol Dimethylhydantoin (DMDMH). 
Antibacterial assay. Each bacterial strain was subcultured in trypticase soy broth overnight at $37^{\circ} \mathrm{C}$. Then the culture was diluted 100 -fold and one loopful of culture was applied to a petri dish containing heart infusion to which an appropriate concentration of DMDMH was added. After incubation for 18 to $20 \mathrm{hr}$ at $37^{\circ} \mathrm{C}$, the growth was observed. Comparative studies of DMDMH with formaldehyde were carried out with $E$. coli and Staph. aureus by the disc method on nutrient agar plates") and the broth culture method, with trypticase soy broth, for the growth inhibitory activity.

Antifungal activity. Spores of each strain were inoculated by streaking on Sabouraud's $2 \%$ glucose agar plates, to which an appropriate concentration of DMDMH was added, followed by incubation for 7 days at $25^{\circ} \mathrm{C}$, and the growth was assessed. The spores of fungi were subcultured in Czapek's medium for Aspergillus species, in Sabouraud's medium for Candida species, both for 7 days at $25^{\circ} \mathrm{C}$, and for Trichophyton and Microsporum species, for 10 days at $25^{\circ} \mathrm{C}$ in Sabouraud's medium. The spore samples inoculated for assays were prepared as suspension, from one loopful of spores and mycelia on the plate of sub. culture, in saline which contained about 1.0 to $1.2 \times 10^{3}$ spores $/ \mathrm{ml}$

Bacteriostatic or bacteriocidal? Sarcina lutea PCI 1001 was used for this purpose. One $\mathrm{ml}$ of fully grown bacteria, which has reached a stationary phase after standing in trypticase soy broth at $37^{\circ} \mathrm{C}$ for overnight, was diluted to $10 \mathrm{ml}$ with the same broth. The growth was continued at $37^{\circ} \mathrm{C}$ under reciprocative shaking for $1 \mathrm{hr}$. Then aliquots of the culture were separated and DMDMH was added to the bacterial suspensions to give final concentrations of 1 and $0.1 \%$ respectively. After incubation with the chemical for $10,30 \mathrm{~min}$, 1 and $4 \mathrm{hr}$, the bacteria were separated and washed by centrifugation with fresh media twice. Then incubation was resumed in fresh media at $37^{\circ} \mathrm{C}$ for $30 \mathrm{~min}$ under shaking, followed by an inoculation of a loopful of culture to a nutrient agar plate and then incubation was allowed to continue for overnight.

Effect on mammalian cells in culture. HeLa S3 cells were grown in a test tube $(1.3 \times 11.0 \mathrm{~cm})$ with $1 \mathrm{ml}$ of culture medium of Eagle's MEM (Gibco, Grand Island, N.Y.) with $10 \%$ bovine serum. Cell growths were determined by colorimetry based on protein content as described by Oyama and Eagle ${ }^{3}$ ) using phenol reagent and by hemocytometer. DMDMH, after dilution with MEM, was added to the culture at $10 \%$ in volume to the media after about $20 \mathrm{hr}$ of cell plating.

In vivo toxicity in mice. Six-week old IRC strain male mice of average body weight of $24 \pm 2 \mathrm{~g}$ were used.
Each group consisted of eight mice. The chemical administered orally or intraperitoneally in the range of $9.76 \mathrm{~g}$ to $0.4 \mathrm{~g}$ per $\mathrm{kg}$ of body weight. Acute toxicity was assessed by the survival rate of the animals of which the victims died within a day or two.

Nuclear magnetic resonance study. The change in the state of proton of DMDMH upon treatment with alkali and the generation of formaldehyde were studied with NMR spectra. The authentic formaldehyde in $\mathrm{D}_{2} \mathrm{O}$ showed a signal at about $\delta 4.79$ (ppm) (not shown). DMDMH (about $0.2 \sim 0.6$ mmole) was treated with an aliquot of $10 \mathrm{~mm}$ to $10 \mathrm{M} \mathrm{NaOD}$ in $\mathrm{D}_{2} \mathrm{O}$ in NMR tube and NMR signals were obtained. $\mathrm{Na}$ salts of 2,2dimethyl-2-silano pentane sulfonate were used as standards (DSS in Fig. 2).

Effect on antigen-antibody reaction. Since DMDMH appears to be applicable as an antiseptic in biological materials, its effect on antiserum was investigated. Antibody protein, antibovine serum rabbit serum after four-fold dilution with saline, which was prepared in this laboratory, was reacted with DMDMH at various concentrations for a period of up to 5 weeks at room temperature. Then antigen-antibody precipitin reaction was carried out in $1.2 \%$ agarose gel in $0.05 \mathrm{M}$ Tris- $\mathrm{HCl}$ buffer at $\mathrm{pH} 8.2$. The antigen used was bovine serum after dilution $(\times 4)$.

\section{RESULTS AND DISCUSSION}

The minimum inhibitory concentrations against various bacteria and fungi are summarized in Table I. Most of the bacterial growths were inhibited in the continuous presence of DMDMH at 125 to $250 \mu \mathrm{g} / \mathrm{ml}$. Fungal growths were inhibited at 15.6 to $125 \mu \mathrm{g} / \mathrm{ml}$. Comparison of formaldehyde and DMDMH was made in growth inhibitory effect against $E$. coli and Staph. aureus (Table II). The effect in broth culture was about $1 / 8$ to $1 / 4$ of that of formaldehyde.* The growth of the HeLa cells was inhibited completely at or above $13.7 \mu \mathrm{g} / \mathrm{ml}$ but partial growth was seen at $10 \mu \mathrm{g} / \mathrm{ml}$ and no inhibition at $6.85 \mu \mathrm{g} / \mathrm{ml}$ or less (results not shown). In acute toxicity studies with mice, the $\mathrm{LD}_{50}$ (oral) was between 3.0 and $4.32 \mathrm{~g} / \mathrm{kg}$, and the $\mathrm{LD}_{50}$ (intraperitoneal) was between 1.32 and

* The minimum inhibitory concentration determined by agar diffusion (disc) method is less than $2 \mu \mathrm{g} / \mathrm{ml}$ for both of these agents against $E$, coli and Staph. aureus. 
Table I. Minimum InhibItory Concentrations of DMDMH against BaCteria AND FungI

\begin{tabular}{|c|c|}
\hline Strain & $\begin{array}{c}\text { MIC } \\
\text { (microgram } / \mathrm{ml} \text { ) }\end{array}$ \\
\hline Salmonella typhi $\mathrm{H}-901$ & 125 \\
\hline Salmonella paratyphi A 1015 & 250 \\
\hline Salmonella paratyphi B 8006 & 125 \\
\hline Salmonella typhimurium & 125 \\
\hline Shigella flexneri $2 \mathrm{a}$ & 125 \\
\hline Shigella flexneri $3 \mathrm{a}$ & 125 \\
\hline Shigella sonnei & 250 \\
\hline Escherichia coli $0-55$ & 250 \\
\hline Escherichia coli Sakai & 250 \\
\hline Escherichia coli $0-6$ & 125 \\
\hline Pseudomonas aeruginosa A3 & 125 \\
\hline Klebsiella pneumoniae & 250 \\
\hline Proteus vulgaris $\mathrm{OX}-19$ & 250 \\
\hline Bacillus subtilis $\quad$ PCI-219 & 250 \\
\hline Staphylococcus aureus 209-P & 250 \\
\hline Staphylococcus aureus Imashige & 250 \\
\hline Staphylococcus aureus STP-182 & 250 \\
\hline Staphylococcus aureus Smith & 125 \\
\hline Staphylococcus aureus Neuman & 250 \\
\hline Sarcina lutea $\quad$ PCI-1001 & 180 \\
\hline Trichophyton asteroides & 15.6 \\
\hline Microsporum gypseum & 15.6 \\
\hline Candida albicans & 125 \\
\hline Aspergillus fumigatus & 125 \\
\hline Aspergillus niger ATCC 9508 & 125 \\
\hline
\end{tabular}

$2.0 \mathrm{~g} / \mathrm{kg}$ of body weight (Table III). The values showed relatively mild toxicity of DMDMH compared with Formalin (Oral $\mathrm{LD}_{50}$, rats: $0.8 \mathrm{~g} / \mathrm{kg}$ ).

Treatment with this chemical at 0.1 and $1.0 \%$ for 10 and $30 \mathrm{~min}$ in broth did not prevent bacterial growth of $S$. lutea when the bacteria were replaced in a fresh medium (agar plate) while $1 \%$ formaldehyde inhibited the subsequent bacterial growth completely (bacteriocidal). After 4 -hr treatment at $1 \%$ complete inhibition was observed, although, 2-hr treatment at $0.5 \%$ was found still insufficient for complete killing. When Sarcina lutea was treated with $1 \%$ DMDMH in the culture broth, there was no change in turbidity, suggesting bacteriolytic activity was not a likely mechanism.

NMR study was performed to clarify the molecular nature of active principle. Upon addition of alkali ( 0.68 mole equivalent of $\mathrm{NaOD}$ to $\mathrm{DMDMH}$, where $\mathrm{pD}$ shifted to about 10.3), the two singlets corresponding to $\mathrm{N}, \mathrm{N}^{\prime}$ hydroxymethyl groups (4.85 and 4.90 ppm) disappeared completely and immediately, and a new peak ( $0.1 \mathrm{ppm}$ lower) correspond-

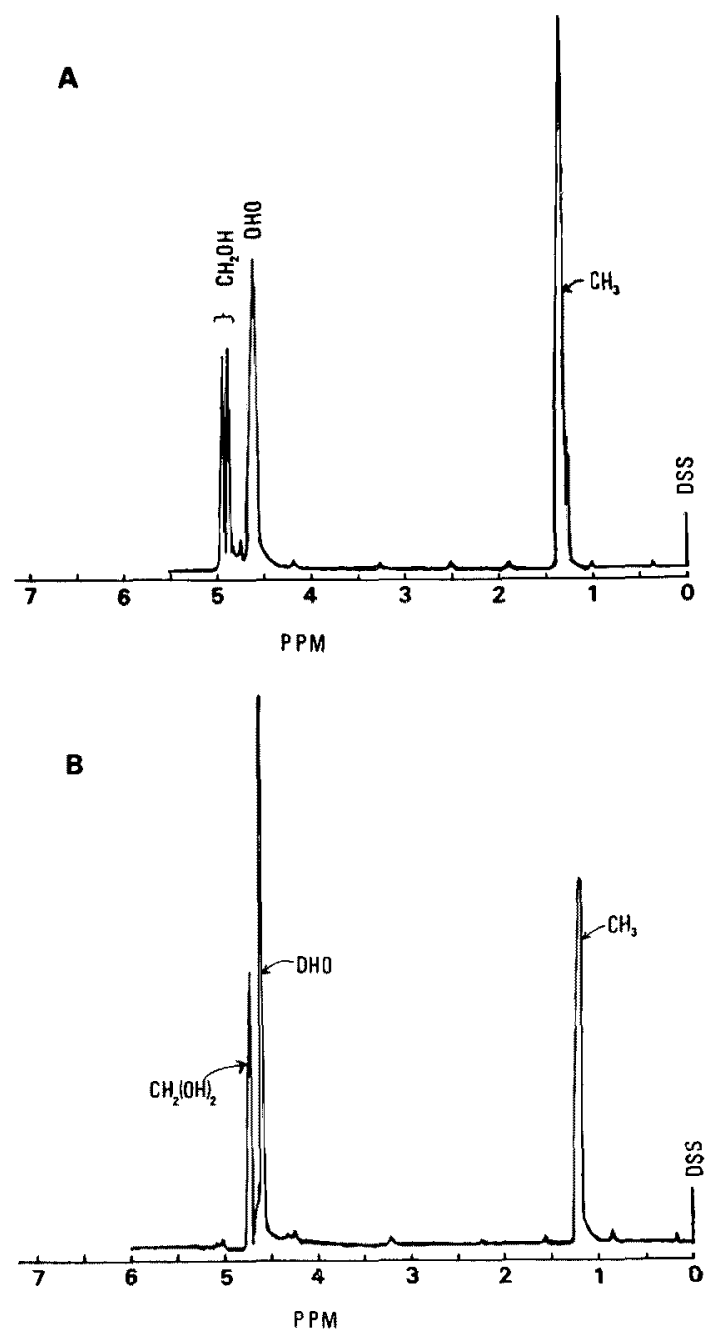

FIG. 2. NMR Spectra of DMDMH before and after Alkaline Ttreatment.

A). Before alkaline treatment, two singlet peaks originating from the peaks of $\left(\mathrm{CH}_{2} \mathrm{OH}\right)$ are shown at 4.85 and $4.90 \mathrm{ppm}$.

B). After addition of 0.68 mole equivalent alkali (pH 10.3), the peaks of $\left(\mathrm{CH}_{2} \mathrm{OH}\right)$ disappeared, and a new peak at 4.79 ppm corresponding to $\left[\mathrm{CH}_{2}(\mathrm{OH})_{2}\right]$ appeared. The intermediate additions of alkali resulted in more complex peaks (4.85 4.73 ppm).

The peak at $4.60 \mathrm{ppm}$ is due to DHO as a contaminant in $\mathrm{D}_{2} \mathrm{O}$. DSS is a reference standard of 0 ppm. Although shown as $\mathrm{CH}_{2} \mathrm{OH}$ and $\mathrm{CH}_{2}(\mathrm{OH})_{2}$ here, those in $\mathrm{D}_{2} \mathrm{O}$ should be $\mathrm{CH}_{2} \mathrm{OD}$ and $\mathrm{CH}_{2}(\mathrm{OD})_{2}$ respectively. 
Table II. Comparison of Minimum Inhibitory Concentrations of DMDMH AND FormaldeHyde IN Broth Culture

Assays were carried out in trypticase soybroth at $\mathrm{pH} 7.4$ and $37^{\circ} \mathrm{C}$ under reciprocative shaking for overnight.

\begin{tabular}{llcccccc}
\hline \multirow{2}{*}{ Bacteria } & \multicolumn{7}{c}{ Concentrations $(\mu \mathrm{g} / \mathrm{ml})$} \\
\cline { 2 - 7 } & Drugs & 500 & 250 & 125 & 62.5 & 31.3 & 15.6 \\
\hline \multirow{2}{*}{ S. aureus, Smith } & DMDMH & - & - & \pm & + & + & + \\
& Formaldehyde & - & - & - & - & - & + \\
\hline \multirow{2}{*}{ E. coli, 0-6 } & DMDMH & - & \pm & + & + & + & + \\
& Formaldehyde & - & - & - & - & + & + \\
\hline
\end{tabular}

TABLE III. In vivo ToXICITY of DMDMH IN Mice

Acute toxicity in vivo was tested with ICR strain male mice 6 weeks old, which had an average body weight of $24 \pm 2 \mathrm{~g}$. Each group consisted of eight mice. N.T. stands for "not tested."

\begin{tabular}{ccc}
\hline $\begin{array}{c}\text { Amount } \\
\text { of drug } \\
(\mathrm{g} / \mathrm{kg})\end{array}$ & \multicolumn{2}{c}{ No. of surviving/No. of treated } \\
\cline { 2 - 3 } & Oral route & $\begin{array}{c}\text { Intraperitoneal } \\
\text { route }\end{array}$ \\
\hline 9.76 & $0 / 8$ & N.T. \\
6.52 & $0 / 8$ & N.T. \\
4.50 & $0 / 8$ & $0 / 8$ \\
4.32 & $0 / 8$ & N.T. \\
3.00 & $8 / 8$ & $0 / 8$ \\
2.00 & $8 / 8$ & $0 / 8$ \\
1.32 & $8 / 8$ & $8 / 8$ \\
88 & $8 / 8$ & $8 / 8$ \\
60 & N.T. & $8 / 8$ \\
40 & N.T. & $8 / 8$ \\
\hline
\end{tabular}

ing to hydrated formaldehyde, methylenediol, $\left[\mathrm{CH}_{2}(\mathrm{OH})_{2}\right]$ appeared (see Fig. 2) which was identified by the authentic formaldehyde and is known to exist as such in water." NMR spectra of the reaction mixtures did not change during a long period of standing. Addition of 0.01 to 0.34 mole equivalent of alkali, giving intermediate $\mathrm{pHs}$, to a mole of DMDMH in $\mathrm{D}_{2} \mathrm{O}$ solution showed only intermediate states in the disappearance of $\mathrm{CH}_{2} \mathrm{OD}$ signals and the appearance of the hydrated formaldehyde signal in their height in which $\mathrm{pD}$ ranged $7.3 \sim 10.0$. The reaction is pH-dependent but not time-dependent. An aldehyde group attached to the alkyl group, if any, should show a signal in a much lower field $(9 \sim 10 \mathrm{ppm})$ and this was not observed at all. Present results therefore favor the principal action mechanism through the formaldehyde production, and the DMDMH itself is found to be a prodrug form.* This was confirmed by dimedone reaction (details to be described elsewhere).

The effect of DMDMH on antibody protein was seen at a high concentration $(2 \%)$ (Table IV). Formaldehyde, however, was found to be more reactive at lower concentrations. At $0.125 \%$, the antibody lost its

Table IV. Effect of DMDMH on Antibody Protein as Revealed by ANTIGEN-ANTIBODY REACTION

The antigen (bovine serum) and the antibody, both diluted four times before use, were reacted in agarose-gel (the double diffusion Oucherlony's method) and the precipitin lines were observed about $30 \mathrm{hr}$ later. The sign + indicates the intensity of precipitin. The sign-means precipitin line undetectable, and thus antibody protein must be modified. See Text for details. The length of the treatment with DMDMH did not affect the antigen-antibody reaction after 2 days. Formaldehyde was used as a reference.

\begin{tabular}{rlllllll}
\hline \multicolumn{2}{l}{ Concentration $(\%)$} & 2 & 0.5 & 0.125 & 0.031 & 0.0078 & 0.0 \\
\hline Chemicals & DMDMH & + & ++ & +++ & +++ & ++++ & ++++ \\
& Formaldehyde & - & - & - & ++ & +++ & ++++ \\
\hline
\end{tabular}

* A similar compound, dimethylhydantoin, which posseses no hydroxymethyl group, did not show any change in the NMR spectra, nor reaction with dimedone nor antibacterial activity. 
precipitin forming capacity completely, while DMDMH at a more than sixteen times higher concentration showed similar inactivation to that of formaldehyde. This antibody inactivation may be due to the rapid modifications of antigen combining site of antibody molecules and their structural integrities by formaldehyde (through the modification of amino and histidyl groups).

The above results reveal a potential applicability of DMDMH as a bacteriostatic antiseptic agent at a relatively low concentration and as a possible substitute for mercurials. Since the toxicity of DMDMH is oral $\mathrm{LD}_{60}$ between 3.0 and $4.32 \mathrm{~g} / \mathrm{kg}$ (in male mice), while that of merthiolate is s.c. LD $_{50} 66 \mathrm{mg} /$ $\mathrm{kg}$ (in mice) $)^{5}$ and that of phenol is oral $\mathrm{LD}_{50} 530 \mathrm{mg} / \mathrm{kg}$ (in rats), ${ }^{5 /}$ and thus DMDMH can be considered less toxic. The discrepancy between the lower toxicity in vivo and the higher toxicity in culture cells may be due to rapid inactivation of DMDMH by serum proteins and other compounds through such reactions as described. In addition to its lower toxicity, DMDMH has a very high solubility. Methyl paraben, for instance, which is a widely used preservative has a much higher minimum inhibitory concentration (about $1000 \mu \mathrm{g} / \mathrm{ml}$ ) and very low solubility in water $(0.25 \%)$. Present study justifies further evaluation in the toxicology and the precise mechanisms of its action at subcellular level.

Acknowledgement. We wish to thank Glyco Chemical Inc. for the supply of DMDMH.

\section{REFERENCES}

1) Glyco Technical Data Bulletin A-104-C. (1973). Glyco Chemicals Inc., Greenwich, Conn., USA.

2) A. W. Bauer, W. M. M. Kirby, J. C. Sherris and M. Turck, Amer. J. Clin. Pathol, 45, 394 (1966).

3) V. I. Oyama and H. Eagle, Proc. Soc. Exp. Biol. Med. (N.Y.), 91, 305 (1956).

4) D. J. Cram and G.S. Hammond, "Organic Chemistry," Second Ed., McGrow-Hill Book Co., Inc., N.Y., 1964, pp. 185.

5) "The Merck Index," 8th ed., ed. by P. G. Stecher, M. Windholz, D. S. Leahy, D. M. Boiton and L. G. Eaton, Merck and Co., Inc., Rahway, N.J., 1968. 